\title{
PENCEGAHAN PENYAKIT AKIBAT KERJA PADA PERAWAT
}

\section{MEGA CERIA PURNAMA ZEBUA}

\author{
Megaceria25@gmail.com
}

\begin{abstract}
ABSTRAK
Latar Belakang. Upaya kesehatan adalah setiap kegiatan dan atau serangkaian kegiatan yang dilakukan secara terpadu, terintegrasi dan berkesinambungan untuk memelihara dan meningkatkan derajat kesehatan masyarakat dalam bentuk pencegahan penyakit, peningkatan kesehatan, pengobatan penyakit dan pemulihan kesehatan oleh pemerintah atau masyarakat. Tersedianya pelayanan kesehatan bagi masyarakat bertujuan agar terselenggaranya pembangunan kesehatan yang baik, yang bertujuan untuk meningkatkan kesadaran, kemauan dan kemampuan hidup sehat bagi setiap orang agar terwujud derajat kesehatan yang setinggi-tingginya. Tindakan tidak aman (unsafe action) adalah tindakan yang dapat membahayakan pekerja itu sendiri maupun orang lain yang dapat menyebabkan terjadinya kecelakaan yang dapat disebabkan oleh berbagai hal seperti tidak memakai APD, tidak mengikuti prosedur kerja, tidak mengikuti peraturan keselamatan kerja dan bekerja tidak hati-hati Metode: Penelitian ini menggunakan jenis penelitian explanatory research Kesimpulan: Salah satu penyebab penyakit akibat kerja yang dialami tenaga medis ialah infeksi nosokomial. Infeksi nosokomial dapat terjadi dikarenakan tertusuk benda tajam akibat limbah suntik yang tidak diolah dengan baik. Untuk itu rumah sakit perlu memperhatikan limbah rumahsakit dan memperhatikan petugas medis agar tetap menggunakan APD sesuai dengan Prosedur
\end{abstract}

Kata Kunci: Infeksi Nosokomial, APD, Penyakit akibat kerja

\section{LATAR BELAKANG}

Rumah sakit merupakan sarana pelayanan kesehatan yang beragam dan memiliki permasalahan tenaga kerja yang mempunyai resiko terkena penyakit akibat kerja bahkan dapat mengancam keselamatan tenaga pekerja tersebut. Untuk alasan itu maka pekerja rumah sakit berkewajiban untuk menjalankan upaya 
pembinaan Keselamatan dan Kesehatan Kerja Rumah Sakit (K3RS) yang bertujuan untuk terhindar dari adanya resiko kecelakan kerja.

Rumah sakit memiliki fungsi
pemberian pelayanan dalam rangka
mendiagnosis, mengobati dan
menyembuhkan penderita sehingga
didapatkan kondisi yang sehat dan bebas
dari penyakit.

Tindakan tidak aman (unsafe action) adalah tindakan yang dapat membahayakan pekerja itu sendiri maupun orang lain yang dapat menyebabkan terjadinya kecelakaan yang dapat disebabkan oleh berbagai hal seperti tidak memakai APD, tidak mengikuti prosedur kerja, tidak mengikuti peraturan keselamatan kerja dan bekerja tidak hati-hati, dimana dari setiap 300 tindakan tidak aman, akan terjadi 1 (satu) kali kecelakaan yang mengakibatkan kehilangan hari kerja.

Rumah sakit menggunakan berbagai bahan,energi,air, udara dan gas. Bahan bahan yang digunakan adalah bahan kimia dan bahan lain untuk keperluan layanan medis maupun non medis.

Pengelolaan limbah rumah sakit adalah suatu upaya yang dilakukan terhadap limbah, mulai dari tahap pemilahan dan pengumpulan di tempat sumber, pengangkutan, penampungan hingga tahap pemusnahan (Djohan \& Halim, 2013). Peran cleaning service dalam pengelolaan limbah terletak pada tahap pemilahan (Indonesia Public Health Information, 2014). Cleaning service harus memilah limbah medis dan limbah non medis serta menempatkannya pada wadah penampung berdasarkan jenis limbah dan/atau sesuai ketentuan yang ada di rumah sakit (Djohan \& Halim, 2013).

Karena limbah tersebut dapat menjadi penyebab infeksi nosokomial. Kejadian infeksi dianggap suatu masalah yang mengancam kesehatan dan kesejahteraan pasien dan petugas kesehatan secara global. Penelitian menunjukan bahwa rata rata resiko transmisi virus melalui Blood-Borne pada kecelakaan tertusuk jarum, dan bebrapa kasus tertujuk benda tajam lainnya.

Perilaku tidak aman perawat saat bekerja tanpa menggunakan alat pelindung diri sesuai standar dapat mengakibatkan kecelakaan kerja dan menimbulkan penyakit akibat kerja. Cedera akibat tusukan jarum pada perawat merupakan masalah yang signifikan dalam institusi pelayanan kesehatan dewasa ini. Ketika perawat tanpa sengaja menusuk dirinya sendiri dengan jarum suntik yang sebelumnya masuk ke dalam jaringan tubuh pasien, perawat beresiko terjangkit 
sekurang-kurangnya 20 patogen potensial (P.I, Wiyono, \& Candrawati, 2015).

Upaya kesehatan adalah setiap kegiatan dan atau serangkaian kegiatan yang dilakukan secara terpadu, terintegrasi dan berkesinambungan untuk memelihara dan meningkatkan derajat kesehatan masyarakat dalam bentuk pencegahan penyakit, peningkatan kesehatan, pengobatan penyakit dan pemulihan kesehatan oleh pemerintah atau masyarakat. Tersedianya pelayanan kesehatan bagi masyarakat bertujuan agar terselenggaranya pembangunan kesehatan yang baik, yang bertujuan untuk meningkatkan kesadaran, kemauan dan kemampuan hidup sehat bagi setiap orang agar terwujud derajat kesehatan yang setinggi-tingginya.

Menurut WHO, 2005 Infeksi nosokomial merupakan salah satu penyebab utama dari meningkatnya angka morbiditas dan mortalitas,yang dapat menghambat proses penyembuhan sehingga mengakibatkan masalah baru dalam bidang kesehatan, antara lain meningkatnya hari rawat dan bertambahnya biaya perawatan serta pengobatan pasien di rumah sakit .

\section{METODE}

Rancangan penugasaan kajian ini menggunakan buku teks, buku referensi, e- book, jurnal dengan menganalisa dan kajian bebas. Penelitian ini menggunakan jenis penelitian explanatory research. Penelitian eksplanatori ( explanatory research ) bersifat penjelasan dan bertujuan untuk menguji suatu teori atau hipotesis guna memperkuat atau bahkan menolak teori atau hipotesis hasil penelitian yang sudah ada.

\section{HASIL DAN PEMBAHASAN}

Hasil yang diperoleh dalam pelaksanaan keselamatan pasien ialah infeksi yang terjadi akibat kecerobohan petugas dapat berkurang dan dapat meningkatkan mutu pelayanan

Dalam KEPMENKES No. 129 tahun 2008 ditetapkan suatu standar pelayanan minimal rumah sakit, termasuk didalamnya pelaporan kasus infeksi nosokomial untuk melihat sejauh mana rumah sakit melakukan pengendalian terhadap infeksi ini. Data infeksi nosokomial dari surveilans infeksi nosokomial di setiap rumah sakit dapat digunakan sebagai acuan pencegahan infeksi guna meningkatkan pelayanan medis bagi pasien (Kepmenkes RI, 2010).

Rumah sakit adalah institusi pelayanan kesehatan yang menyelenggarakan pelayanan kesehatan perorangan secara paripurna yang menyediakan pelayanan rawat inap, rawat 
jalan dan rawat darurat. Rumah sakit merupakan salah satu pelayanan kesehatan yang merupakan unit kerja dengan tugas utamanya memberikan pelayanan medis komprehensif dalam bentuk promotif, preventif, kuratif, serta rehabilitatif. Pelayanan medis dalam bentuk promotif merupakan upaya yang diberikan kepada penderita yang sedang sakit agar penderita dapat meningkatkan.

$\begin{array}{rrrr} & \text { Pelayanan } & \text { Rumah Sakit } & \text { sesuai } \\ \text { fungsi } & \text { diatas } & \text { diharapkan tidak }\end{array}$
mengakibatkan gejala penularan kepada pengguna rumah sakit itu sendiri (infeksi). Penyakit infeksi merupakan penyebab utama tinginya angka kesakitan dan kematian di dunia. Mengingat rumah sakit terkait dengan kondisi yang rawan baik untuk pengelola maupun pengunjung serta pasiennya diperlukan pengelolaan yang sangat serius mengingat beberapa jenis kuman dapat tumbuh dan berkembang sesuai kondisi ideal yang dibutuhkan oleh jenis kuman tersebut.

Banyak faktor yang mempengaruhi penularan infeksi nosokomial pada pengelolah limbah medis padat, diantaranya :

- personal hygiene, alat pelindung diri (APD),

- imunisasi,
- masa kerja/pengalaman kerja

Kasus infeksi nosokomial dapat terjadi disetiap saat dan dapat pula terjadi dimana saja disetiap ruang perawatan. Hal ini sangat berpengaruh pada besarnya hari lama rawat setiap pasien di rumah sakit, sehingga juga berdampak besar terhadap keefektifitasan rumah sakit. Selain itu, infeksi nosokomial sangat menyangkut pada keselamatan pasien, berdasarkan peraturan departemen kesehatan RI tentang keselamatan pasien, dikatakan bahwa keselamatan pasien harus di prioritaskan agar dapat menurunkan kejadian tidak di inginkan oleh pihak rumah sakit. Besarnya pengaruh masalah infeksi nosokomial terhadap manajemen rumah sakit, perlu adanya kegiatan pencatatan dan perolehan data mengenai infeksi nosokomial di rumah sakit.

Surveilans dilakukan sebagai acuan bagi pihak manajemen rumah sakit untuk mengambil kebijakan serta keputusan, dan mengevaluasi mengenai kejadian infeksi nosokomial sebelumnya. Surveilans merupakan kegiatan epidemiologis 
dengan cara memperoleh, mengolah dan menganalisis data dikarenakan adanya temuan kasus yang harus di amati riwayat penyakit sebelumnya.

Tenaga kesehatan termasuk perawat wajib menjaga kesehatan dan keselamatan dirinya dan orang lain serta bertanggung jawab sebagai pelaksanaan kebijakan keselamatan dan kesehatan pasien yang telah ditetapkan. Tenaga kesehatan juga bertanggung jawab dalam mengunakan sarana yang telah disediakan dengan baik dan benar serta memelihara sarana agar selalu siap pakai dan dapat dipakai selama mungkin. Dan bertanggung jawab dari segala tindakan yang diberikan kepada pasien. Tanggung jawab tersebut meliputi:

- Bertanggung jawab melaksanakan dan menjaga kesalamatan kerja.

- Mengetahui kebijakan dan menerapkan prosedur kerja, pencegahan infeksi, dan mematuhinya dalam pekerjaan sehari-hari.

- Tenaga kesehatan yang menderita penyakit yang dapat meningkatkan resiko penularan infeksi, baik dari dirinya kepada pasien atau sebaliknya, sebaiknya tidak merawat pasien secara langsung atau dapat menggunakan pelindung seperti masker.

- Bagi tenaga kesehatan yang megidap HIV mempunyai kewajiban moral untuk memberi tahu atasannya tentang status serologi bila dalam pelaksanaan pekerjaan status serologi tersebut dapat menjadi resiko pada pasien

Komponen utama standar pencegahan dan pengendalian infeksi nosokomial dalam tindakan operasional mencakup kegiatan sebagai berikut:

1. Mencuci tangan Mencuci tangan sebaiknya dilakukan pada air yang mengalir dan dengan sabun yang digosokkan selama 15 sampai 20 detik. Mencuci tangan dengan sabun biasa dan air bersih adalah sama efektifnya mencuci tangan dengan sabun antimikroba. Ada beberapa kondisi yang mengharuskan petugas kesehatan menggunakan sabun antiseptik ini, yaitu saat akan melakukan tindakan invasif, sebelum kontak dengan pasien yang dicurigai mudah 
terkena infeksi (misalnya: bayi yang baru lahir dan pasien yang dirawat di ICU).

2. Menggunakan alat pelindung diri/APD seperti: sarung tangan, masker, pelindung wajah, kacamata dan apron pelindung. Alat pelindung diri yang paling baik adalah yang terbuat dari bahan yang telah diolah atau bahan sintetik yang tidak tembus oleh cairan.

3. Praktik keselamatan kerja Praktik keselamatan kerja berhubungan dengan pemakaian instrumen tajam seperti jarum suntikndari menutup kembali jarum suntik yang telah digunakan. Bila terpaksa dilakukan, maka gunakan teknik satu tangan untuk menutup jarum, hindari melepas jarum yang telah digunakan dari spuit sekali pakai, hindari membengkokkan, menghancurkan atau memanipulasi jarum suntik dengan tangan serta masukkan instrumen tajam ke dalam wadah yang tahan tusukkan dan tahan air.

4. Perawatan pasien rawatan pasien yang sering dilakukan meliputi tindakan: pemakaian kateter urin, pemakaian alat intravaskular, transfusi darah, pemasangan selang nasogastrik, pemakaian ventilator dan perawatan luka bekas operasi.
Kateterisasi kandung kemih membawa risiko tinggi terhadap infeksi saluran kemih (ISK).

\section{KESIMPULAN}

Rumah sakit merupakan sarana pelayanan kesehatan yang beragam dan memiliki permasalahan tenaga kerja yang mempunyai resiko terkena penyakit akibat kerja bahkan dapat mengancam keselamatan tenaga pekerja tersebut.

Salah satu penyebab penyakit akibat kerja yang dialami tenaga medis ialah infeksi nosokomial. Infeksi nosokomial dapat terjadi dikarenakan tertusuk benda tajam akibat limbah suntik yang tidak diolah dengan baik.

Untuk itu rumah sakit perlu memperhatikan limbah rumahsakit dan memperhatikan petugas medis agar tetap menggunakan APD sesuai dengan Prosedur.

\section{DAFTAR PUSTAKA}

DepKes, R. (2009). Pedoman Pencegahan dan Pengendalian Infeksi di RS dan Fasilitas Pelayanan Kesehatan Lainnya.

Djohan, \& Halim. (2013). Pengelolaan Limbah Rumah Sakit. jakarta: Salemba Medika.

Indonesia, P. M. (2017). Tentang Keselamatan Pasien Nomor 11.

Isnaini, N. (2014). Pengalaman perawat pelaksana dalam menerapkan keselamatan pasien. Jurnal Manajemen Keperawatan. 
KemenKes, R. (2011). Pedoman

Pencegahan dan Pengendalian

Infeksi di Rumah sakit dan Fasilitas

Pelayanan Kesehatan Lainnya.

Kepmenkertrans. (2010). Alat Pelindung

Diri.

Kusnan. (2017). infeksi Nosokomial

Playanan kesehatan. Yogyakarta:

Leukaprio.

P.I, S. M., Wiyono, J., \& Candrawati, E. (2015). Kejadian Kecelakaan Kerja Perawat Berdasarkan Tindakan Tidak Aman. Jurnal Care.

Salawati, L. (2012). Pengendalian Infeksi Nosokomial Di Ruang Intensive Care Unit . Jurnal Kedokteran Syiah Kuala.

Salawati, L. (2015). PENYAKIT AKIBAT KERJA DAN PENCEGAHAN. Jurnal Kedokteran Syiah Kuala.

Simamora, R. H., \& Nurmaini. (2019). Knowledge of Nurses about Prevention of Patient Fall Risk in Inpatient Room of Private Hospital in Medan. Indian Journal Of Public Health Research \& Development. 